\author{
TAMARA R. KOVAČEVIĆ ${ }^{1}$ \\ LJUBICA S. ISAKOVIĆ ${ }^{2}$ \\ UNIVERSITY OF BELGRADE \\ FACULTY OF SPECIAL EDUCATION AND REHABILITATION \\ RADOMIR B. ARSIĆ ${ }^{3}$ \\ UNIVERSITY OF PRIŠTINA IN KOSOVSKA MITROVICA \\ FACULTY OF TEACHER EdUCATION IN PRIZREN - Leposavić
}

\title{
BILINGUAL APPROACH IN THE EDUCATION OF DEAF AND HARD OF HEARING CHILDREN
}

ABSTRACT. The bilingualism of deaf and hard of hearing children implies the knowledge and regular use of sign language, which is used by the community of deaf people, and of spoken language, which is used by the hearing majority. At preschool and school age, it is necessary to allow children to continue adopting the language that they started in the family (either sign language or spoken language). Children will adopt both language modalities best through interactions with other fluent speakers. Results of numerous studies indicate that the best approach in the process of development of speech and language and the education of the deaf and hard of hearing children is the bilingual approach. The aim of this approach is to develop communication skills in children, to provide a higher level of education for them, and to include them in the life of the community. It is necessary to improve the existing education system in the direction of developing a kind of a model that will re-

\footnotetext{
122tamara@gmail.com

ljubicaisakovic07@gmail.com

radomir.arsic@pr.ac.rs
}

The paper is from the Project of the Ministry of Education, Science and Technological Development of the Republic of Serbia entitled The Effect of Cochlear Implantation on the Education of Deaf and Hard of Hearing Persons, No. 179055.

This paper was submitted on October $15^{\text {th }}, 2019$ and accepted for publication at the meeting of the Editorial Board held on December $3^{\text {rd }}, 2019$. 
spond to their specificities and limitations caused by their primary impairment.

KEYWORDS: bilingual approach; education; deaf and hard of hearing children.

\section{INTRODUCTION}

For many years, in the world and in our country, there have been debates on how and in which way it is best to approach the education of deaf and hard of hearing children, as well as which approach and model of education will be most successful and contribute most to adequate achievements and acquisition of knowledge. The population of deaf and hard of hearing children is very heterogeneous and, because of this, the existence of different approaches is needed in education in order to meet their communication and educational needs successfully. Hearing and speech impairment leads to certain specificities and difficulties in the development of these children, which require adequate methods and approaches in the process of rehabilitation and education, and great support and encouragement from the family, the preschool institution, the school, and the environment. A large number of authors point to the importance of the use of sign language as well as the need for the parallel use of both oral and sign methods in the form of bilingualism (Swanwick, 2016). Results of numerous studies indicate that the best approach in education, for most deaf children, is bilingualism, or bilingual approach (Gregory, 2004; Mahshie, 2007; Marschark \& Spencer, 2010; Wilbur, 2000). Bilingualism is knowledge and regular use of sign language and speech in deaf and hard of hearing children. Authors who studied the early use of the sign language and its influence on the adoption of language, find that the deaf children who communicated in sign language with their parents early and who had bilingual education achieved better results in language skills at the end of their schooling (Hoffmeister, 2000; Komesaroff, 2001; Kovačević, 2013).

\section{BILINGUALISM OF DEAF AND HARD OF HEARING CHILDREN}

Bilingualism refers to the phenomenon of knowledge and regular use of two languages. Many studies speak of the positive impact of bilingualism or the adoption of a non-native language on the development of various forms of meta-language ability. This leads to the conclusion 
that the adoption of language is not only a process of acquiring communication skills, but also a formative factor that influences the overall psychological development of a child (Titone, 1994). Research in the field of bilingualism and cognitive functioning has shown that early bilingualism and constant, everyday use of two or more languages lead to earlier maturation of certain cognitive processes in children (Bialystok, 2001, p. 6). Bilingualism of the type "sign language - spoken language" is the only way for a deaf child to meet their needs, i.e. to communicate with their parents from an early age, to develop their cognitive abilities, to get to know the world, to communicate fully with the environment, and to acculture themselves to the world of those who hear and the world of the deaf (Grosjean, 2001). Sign and spoken languages include various perceptive and productive systems. While spoken languages include mechanisms of auditory processing and speech production, sign languages are perceived visually and their articulation includes systematic use of parts of the body and space. Sign languages have evolved in a biological medium different from that of spoken languages. But, in spite of evident differences in modality, they are structured as spoken languages at the phonological level, morphological level, and syntactic level (So, Coppola, Licciardello, \& Goldin-Meadow, 2005). Sign language is the language that the deaf children adopt and learn spontaneously, just like the hearing children adopt the spoken language of their environment. Deaf children who have, since the earliest age, been exposed exclusively to sign language, go through the same basic stages of language acquisition as hearing children who learn to speak in their environment (Kovačević, 2012; Kovačević, Isaković \& Dimić, 2016). When a deaf or hard of hearing child develops a good linguistic foundation through the natural adoption of the first sign language, that linguistic competence can be used as a support for learning of another, hardly accessible, spoken language. This does not mean that all deaf and hard of hearing children can develop full and functional speech abilities. In order to become bilingual, every deaf child has to be purposefully exposed to the influence of both languages. For many hearing children, this occurs naturally when it is possible to tell the difference between the language spoken in the family and the language of the social environment. The strategy of being exposed to the influence of two languages, for most bilingual children, aims at providing the children with full access to at least one language, through: determining the individuals that will use both languages in front of the child; determining the time in which each language will be used; 
using one language at home and the other outside it or using both languages at the same time, shifting from one to another (Graney, 2002; according to Soleša-Grijak, 2010).

When teaching deaf children sign language and spoken language, the most important thing is to provide an environment and situations that are stimulating enough to motivate a child to communicate using both languages. One of the basic assumptions of the bilingual development of deaf children is that it is necessary to provide them with opportunities to communicate interactively with both peers and adults, both with hearing and deaf people, both in sign language and in spoken language. It should be borne in mind that the language has its own spoken, written, and sign expression, and these expressions should be used both together and individually (Ardito, Caselli, Vecchieti \& Volterra, 2008). The bilingualism of the hearing persons is different from the bilingualism of the deaf. Bilingual hearing children learn two languages, just like the deaf children do. The difference is that the second language (L2) is learned in auditory manner, in the same modality as the first language (L1) (Knight \& Swanwick, 2002).

Deaf children learn two languages, in two modalities, which is much more complex. When hearing children are learning a second language (L2), it is completely accessible to them and it is not limited by any physical factors. Deaf children cannot hear their second language (L2) completely. There are also differences in the way of adopting the first language (L1). Most of the hearing children from language minorities learn their first language at home, from their parents, and they begin adopting a second language (L2) at school. For the deaf children of deaf parents, this path is similar, i.e. they adopt sign language naturally at home and they learn a second language (L2) formally at educational institutions, although they often adopt both languages at the same time. For the deaf children of hearing parents, this experience is most often different. In most cases, the hearing parents yet need to learn the child's L1 (sign language), so parents and the child adopt / learn sign language at the same time. The deaf children of deaf parents are, in everyday situations, surrounded by their (L1) in the family, as opposed to the situation of the deaf children of hearing parents. In the deaf children of hearing parents, the educational institution is responsible for the affirmation of sign language, the culture and identity of the deaf, and it is important for connecting the family with the community of the deaf. In hearing children, the adoption of a spoken form of (L2) reflects the processes that have been involved in the adoption of (L1), as well. Most deaf children 
have not adopted (L1) when starting school, in the way most of the hearing children have (Bradarić-Jončić \& Kolarić, 2012). The languages of the hearing persons have a spoken form and a written form. When learning the written form of (L2), hearing children have the help of the spoken form of (L2) and the written form of (L1). Unlike them, the (L1) of the deaf children (sign language) does not have a written form, so deaf children begin to learn reading and writing in (L2) with no previous experience of reading and writing in (L1). This represents an entirely new way of communication for them.

The recognition of the linguistic status of sign languages made it possible for an idea to occur about the application of theoretical and practical findings in the field of bilingualism, i.e. bilingual development of hearing people, in the field of education of deaf children. In the last decades, bilingual-bicultural approach to the education of deaf children was coming to the fore more and more.

\section{BILINGUAL-BICULTURAL MODEL IN THE EDUCATION OF DEAF CHILDREN}

The bilingual-bicultural approach to educating deaf children has been very well designed and developed in the Scandinavian countries (Sweden and Denmark), and increasingly so in the other countries of Europe, America, and Australia, as well. The model of bilingual education is called the "Bi-Bi model" (bilingual-bicultural), i.e. a bilingual-bicultural model that implies the restructuring of the entire system of the education of the deaf, from early childhood, preschool institutions, schools, to faculties. This model implies the inclusion of children in the life of the deaf community, socializing with peers and adults, as well as the education of hearing parents of the deaf children in communicating in sign language. It begins with the application of early intervention programs in working with hearing parents and little deaf babies. Through early intervention programs, hearing parents are enabled to: learn the national sign language; have advisory assistance with regards to the treatment of the child; involvement in the life of the deaf community; socializing with adult deaf people and deaf peers of their deaf children.

Deaf adults play an important role as models of speech and social identification of deaf children. Education and employment of deaf teachers in kindergartens and schools for deaf children is necessary, as well. Young deaf persons are provided with university education 
with the support of an interpreter. In school work, new contents are first covered in sign language, and then in spoken language, whereby the integrity of the input of language information is ensured through the use of written word. It is important that a child understands that these are two separate languages, as a premise of transfer from the first to the second language. In communication and learning, the manually coded language of the hearing majority (speech followed by the sign) is not used, the original sign language of the deaf community is used instead. Deaf students learn about the specificities of the culture of the majority community in which they live, but also about the different specifities of their cultural community-history, artistic creation, customs, and values of the deaf community.

The identification and recognition of sign languages in the world has resulted in changes in the policy of educating deaf children. Thirty years ago, bilingual schools for deaf children-in which sign language has the status of the first language, and the language of the hearing environment is learnt by deaf children as a second languageappeared in the world. In bilingual schools, deaf children learn both languages (sign and speech), adopt meta-language knowledge about them, develop expression and creation in both languages, get to know both cultures, and the teachers know both forms of expression. Evaluation of such forms of the education of deaf children has shown excellent results (Kovačević, 2013).

\section{APPLICATION OF BILINGUAL APPROACH WITH THE DEAF AND HARD OF HEARING CHILDREN OF PRESCHOOL AGE}

Early bilingualism in deaf and hard of hearing children (knowledge of sign language and spoken/ written language) is of great importance for their development. Appropriate and effective early communication, regardless of the language modality (sign or speech) within which it is taking place, together with the acceptance of the child and its impairment, is the basis of successful cognitive development and development of the personality of the child, which is the basis of communication and development of language skills (Perniss, Pfau \& Steinbach, 2007).

Early detection of the child's hearing impairment, and the implementation of an early intervention program as early as possible, are necessary. It is ASHA's (American Speech-Language-Hearing Association) recommendation to develop appropriate early intervention 
programs aimed at families, which provide the experts, the parents, and children with hearing impairments, with a possibility to choose. The family of the hearing impaired child needs to have access to all information on the general development of the child, specific information on the hearing impairment, communication capabilities, and the language development of deaf children. The local community, state, health and educational projects have to direct their aim towards early detection of hearing impairments and early intervention (ASHA,2001; Kovačević, Isaković \& Arsić, 2017).

About $90 \%$ of deaf children were born in families where both parents are hearing persons, $7 \%$ have one deaf parent, and only $3 \%$ have both parents that are deaf (Marschark, Schick \& Spencer, 2006). About $5-10 \%$ of deaf children adopt the sign language from their deaf parents (Mitchell \& Karchmer, 2004). Most of the deaf children grow in a completely hearing world, in their early childhood. Also, most of the hearing parents of deaf children do not know or have little knowledge of sign language, which has significant implications for the development of a deaf child. Children who do not learn their native tongue since birth, learn sign language once they come into contact with their peers at a preschool institution or school.

For a deaf child, since the earliest age, frequent, continuous interactions with exemplars who are fluent in sign language are considered to be of key importance. Hearing parents can do a lot in the beginning, if they build their own awareness of what it means to communicate visually, and begin communicating using only a few signs that are a part of their daily interaction. The first three years of their lives are very important for the adoption of languages in children. Numerous studies indicate that bilingual children function at a significantly higher level than monolingual children, as shown by different measurements of cognitive abilities.

Experiences from Sweden and Denmark indicate that the ultimate goal is for the children to become bilingual adults. Linguist Ahlgren (1994) points out that little deaf children become extremely interested in sign, spoken, and written languages in their surroundings if their natural curiosity is encouraged. The results of longitudinal studies conducted by the Department of Psychology at the University of Stockholm indicate that some of the hearing impaired pre-schoolers who used primarily sign language with their peers (the deaf and hard of hearing ones) and with hearing preschool teachers in preschool institutions were good at spoken Swedish and they used it with their parents, relatives and hearing peers. They were changing their way of 
communication depending on their partner's predispositions (Mahshie, 2007, p. 85).

At preschool age, the task of kindergarten is to enable children to continue adopting the language they have started adopting in the family, and it will be best adopted through interactions with other fluent speakers, adults and children. It is important that a deaf teacher or sign language interpreter are present in the kindergarten to ensure further development of sign language through story-telling and watching stories in sign language on DVD, with retelling, dramatization, and other procedures for encouraging the development of sign language skills. The program that is realized in kindergarten is a regular program of preschool education, just like for the hearing children, only here it is realized in sign language (Teruggi, 2000, according to Bradarić-Jončić \& Kolarić, 2012). Special attention, in the preschool period, is paid to the development of interest in the written word, by reading picture books with translating them to sign language, creating diaries / dictionaries with both pictures and words and constant exposure to the written word through inscriptions on objects in the areas where the child is staying. At the preschool age, it is worked on the development of meta-language awareness with the aim of understanding the separation of the two languages and preparing for later formal studying of grammar. In this period, children are not explicitly explained the grammar rules of sign language and spoken language, but the meta-language awareness is developed through games with signs such as imitating signs, games with signs where certain shapes of the hand are used; telling stories while using only one shape of the hand; children's poetry in sign language; playing with signs in a creative way (for example, varying the sign for the name); the use of bilingual alphabet cards that contain a picture of an object / the first letter / dactylological signs / the shape of a hand with which the sign for that word is created, the word/sign for that object (Bradarić-Jončić \& Kolarić, 2012). In educational work, at preschool age, the following should be provided: participation of a hearing teacher and an assistant who is fluent in sign language; adequate training in sign language for the parents; encouraging the child to start school with already developed first language, either spoken or sign language (Plaza-Pust, 2017, p. 60).

It is known that there are certain rules that need to be respected in order to avoid difficulties in learning two languages in children of an early age: 1) the principle of "one person-one language" has to be respected: every participant in communicating with the child has to be 
consistent and use only one language and avoid switching from one language to another; 2 ) in later stages of language adoption, the child should be given an opportunity to communicate with as many people as possible; in the beginning it is enough for one adult to communicate with a child in only one language, but later the child needs to also communicate with other people in that language, too, and to experience similar contexts in both languages; 3 ) the child should be motivated to use both languages and experience the environment and situations in which it is necessary to use them so that he/she understood. Knowledge of the first, mother tongue will positively influence the learning of another language (Ardito, Caselli, Vecchieti \& Volterra, 2008).

\section{BILINGUAL EDUCATION OF THE DEAF AND HARD OF HEARING CHILDREN OF SCHOOL AGE}

The latest recommendations of the World Federation of the Deaf (WFD) indicate the importance of sign language, and relate to the application of four principles that imply the rights to the use of sign language: 1) recognition of sign language, which includes respect for the culture and identity of deaf people; 2) bilingual education that includes lifelong education in sign language and spoken language for deaf and hard of hearing persons; 3 ) having access to all segments of social life and the implementation of legislation that guarantees fairness and protection against discrimination; 4) providing an interpreter or sign language interpreter that facilitates communication between the deaf and hearing persons. The recommendations of the World Federation of the Deaf refer to the recognition and implementation of sign language that also include respecting the culture and identity of deaf people as well as advocating bilingual and lifelong education in sign language and spoken language for the deaf and hard of hearing persons (Batterbury, 2012).

The connectedness of sign language and spoken language in terms of their mutual support for the more successful development of deaf and hard of hearing children was confirmed by many international studies in the last two decades. This is one of the recommendations for an approach in the education for deaf people. Parents and teachers need to be assured that the language that the child speaks at home (the first language) is adequately developed before they start taking care of the progress of the second language. This implies that the first 
language is crucial to the emotional and educational well-being of the child that its development should be viewed as the highest priority. Many theoreticians of bilingual education agree that competence in the first language clearly contributes to the ability to learn other languages (Francis, 2005).

Cummins (2000) developed a model of linguistic interdependence based on the premise that there are common knowledge and skills for all languages. The model developed as a result of discussions on whether cognitive / academic skills and literacy achieved in one language can be transferred to the learning of the same skills in another language (Reyes, 2006). The model promotes the bilingualism of hearing children when they master the skills of reading and writing in their mother tongue, because this acquired knowledge can be transferred to another language, the language of the social environment (Hoffmeister, 2000; Strong \& Prinz, 2000).

The bilingualism of deaf persons differs from the bilingualism of hearing persons. With minimal access to the oral-auditive communication channel, most of the deaf children fail to develop comprehensible speech, but succeed in mastering the sign language skills succesfully. Sign language is the first, native language, and in face-to-face communication it is equal to any other language that is primary. This does not apply to the written form of sign language, because it does not exist. Thus, when it comes to written communication, a deaf child has to learn the written form of a spoken language (Soleša-Grijak, 2010).

As one of the linguistic abilities, the metalinguistic awareness of the deaf children refers to the awareness of the separation of sign language and spoken language and their existence as two mutually independent linguistic modalities. The development of the metalinguistic awareness in deaf children tells us when and how the deaf child realized that it was in a bilingual situation and how this knowledge influences its development (Swanwick, 2016).

Cummins (2000) points to the interdependence that exists between the bilingual person's two languages, where the development of one language strongly stimulates the development of a second language (Tang, Lam \& Yiu K, 2014). Learning a second language whilst the first language is not yet fully developed may result in a delay in the development of, or loss of knowledge of the first language. Concluding that the child is slow in both the first and the second language does not necessarily mean that the child has a language disorder. The experience of teachers in the US, Sweden, and Denmark indicates that if the 
first language is not well developed, the improvement of the second language and educational achievements will probably not be adequate. Cummins (2000) emphasized a very important difference in the level of language competence: Basic Interpersonal Communication Skills (BISC) - basic skills in interpersonal communication and Cognitive Academic Language Proficiency (CALP) - cognitive language skills. BICS is a level of language activity that is sufficient for basic interaction in which the speaker can rely entirely on the context and where the content can often be predicted. CALP is the level of language competence that is needed for critical thinking, problem solving, and adopting new information. Barnum (1984) refers to the distinction between BICS and CALP in the discussion of the common misconception that speech skills in deaf and hard of hearing children are equal to actual language competence. Numerous studies with deaf children show that they do not have the adopted conversational language (BICS), while in schoolwork they are asked to adopt the academic language (CALP). They must not at the same time adopt language and school knowledge in that language, because the development of skills in the second language depends on the development of skills in the first language. Conditions for the deaf children to learn a second language successfully are fully adopted L1, full accessibility of L2, clear separation of the two languages, intense exposure to L2, i.e. many opportunities for the purposeful use of $\mathrm{L} 2$ in realistic communication contexts. Although the monitoring of the child's achievement or a surface level of competence in relation to both languages can be informative for parents and teachers, it is very important to be aware of the problems related to a deeper linguistic competence needed for thought processing at a higher level, dialogue, and educational work. These problems are not always visible in early childhood-the period in which most communications are spurred by context and / or focused on activity and play-and therefore, they need to be specially observed and studied (Mahshie, 2007, p. 91). A positive effect on the intellectual development of a bilingual child occurs only when he/she achieves a high threshold of linguistic knowledge in both languages. If the child has a low threshold of linguistic knowledge in both languages, and it doesn't know either the first or the second language sufficiently (to the level common for a person with the adopted standard of the first language), the emergence of semilingism or semi-language occurs, which affects the cognitive development and educational achievements negatively. 
The deaf children of deaf parents achieve significantly better results than the deaf children of hearing parents. They control the language of the hearing environment better, have better school achievements, are emotionally more mature, have greater self-esteem, are more independent, have less behavioral disorders, even achieve better results on nonverbal tests of intelligence than the deaf children of hearing parents. They have shown that sign language is useful, and not harmful, for the overall development of the child (Marschark, Schick \& Spencer, 2006).

In the school period, the deaf children are exposed to inputs of various language information through various language situations. The use of languages (the spoken, sign, and written one) and simultaneous communication within a bilingual approach should be planned, i.e. each language is used for precisely defined purposes (Knight \& Swanwick, 2002).

Sign language is used for getting to know and explaining new signs / terms; giving detailed instructions for performing the tasks that pupils need to complete, explaining the instructions previously given in spoken language or simultaneously; explaining language forms from another language, often with the use of the written form, as well as introducing discipline in the classroom. Spoken language is used for simple everyday communication and for the purpose of learning the spoken language: for introducing and designing new expressions in the spoken language; correcting the child's use of spoken language through repetition; asking familiar questions. Simultaneous communication is used for learning the spoken language. Speech was followed by signs, for easier understanding. Deaf children are helped in reading the spoken language, and teachers in hearing comprehension of what the deaf child is saying. It is used for easier understanding when practising spoken language, for example when reading, retelling. It is used to explain words and / or contexts in spoken language, reading practice, asking questions in spoken language, retelling the text from L2. Written language is not often used for giving instructions and giving explanations, but as a support for learning spoken language, for example for introducing new words and phrases from another language, with an explanation in sign language, in speaking exercises, with dactylology (Bradarić-Jončić and Kolarić, 2012).

The model of bilingual education of deaf children includes the following principles: 1) deaf children will learn if they have access to what they want to learn; 2) the first language of a deaf child should be natural sign language; 3 ) adoption of natural sign language should be- 
gin as early as possible in order to take advantage of the critical period; 4) the best models for natural adoption of sign language, the development of social identity and self-esteem of deaf children are deaf people who use sign language fluently; 5) the natural sign language that has been adopted by a deaf child provides the best access to educational content; 6) sign language and spoken language are not the same and they should be separated both in use and in teaching; 7) learning spoken language is, for the deaf people, a process of learning another language by acquiring literacy skills (reading and writing); 8) speech should not be used as primary means of learning the language of the hearing persons; 9) deaf children should not be viewed as "defective" models of the hearing children; 10) the least restrictive environment for a deaf child is the one in which it can naturally adopt sign language and through that language have access to another language and educational content (Johnson, Lydell \& Erting, 1989, p.15; Plaza-Pust, 2017, p. 51).

\section{APPLICATION OF THE BILINGUAL APPROACH IN REGULAR EDUCATION}

Over the last few decades, in developed countries and in our country, there has been a steady increase in the number of deaf and hard of hearing children in regular education conditions. Bilingual approach in the education of deaf children can be successfully implemented in regular education and training conditions, in regular preschool institutions and schools, through bilingual programs for the education of deaf children and the presence of sign interpreters, educational translators. In the new models of integration of deaf children, which are more and more present in the world, efforts are being made to align the aims and requirements of the traditional models of educational integration and the requirements contained in the models of bilingual-bicultural education of the deaf. Such integration, as a rule, implies the so-called co-teaching (team teaching, cooperative teaching) model, where, along with the regular teacher, a sign language interpreter and a teacher for deaf children participate (Kreimeyer, Crooke, Drye, Egbert \& Klein, 2000).

Teachers, and teachers in kindergartens, should be provided with additional education on the specificities of hearing disorders and the education of deaf and hard of hearing children. The support that influences the educational achievements of deaf and hard of hearing 
children in regular educational institutions includes the degree and type of support by teachers and special education teachers, customized communication, appropriate amplification, precise interpreting into sign language, and appropriate visual and acoustic surroundings (Luckner \& Muir, 2001; Schick, Williams \& Kupermintz, 2006). For communicating with deaf and hard of hearing children, it is important to have equal access to information (Isaković and Kovačević, 2015). For the deaf children that use sign language, interpretation into sign language should be provided; for those who use written language, it is necessary to provide subtitles in the national spoken language; for children who prefer lip reading in a combination with listening it is necessary to have support from a speech interpreter. For the hard of hearing children, it is necessary to provide optimal conditions for receiving acoustic information by using, for example, FM (frequency modulation) systems in classrooms, or inductive loop at public events.

CONCLUSION The application of bilingual approach in education has shown good results in many countries, so it is necessary to provide such a model of education in Serbia, as well. The goal of an education reform is for deaf and hard of hearing children, as well as the hearing ones, to have the right to education in their national sign language and the spoken language that is spoken by the majority. It is important to give the parents free choice, so that they can, depending on their child's capabilities, choose oral or bilingual approach to education. What kind of communication will deaf and hard of hearing children use and develop depends largely on whether they originate from a family with deaf parents or from a family with hearing parents. In regular schools, the training and education of teachers, as well as sign language interpreters, should be encouraged.

REFERENCES Ahlgren, I. (1994). Sign Language as the first language. In: I. Ahlgren \& K. Hyltenstam (Eds.), Bilingualism in Deaf education. International studies on Sign Language and communication of the Deaf, 27 (pp. 55-60). Hamburg: Signum-Verlag.

Ardito, B., Caselli, M.C., Vecchietti, A., Volterra, V. (2008). Deaf and hearing children: reading together in preschool. In: C. Plaza-Pust \& E. Morales-Lopez (Eds.), Sign Bilingualism. Language development, interaction, and maintenance in sign language contact situations (137-164). Philadelphia: John Benjamins Publishing Company. 
ASHA-American Speech - Language - Hearing - Association (2001). Year 2000 position statement: Principles and guidelines for early hearing detection and intervention programs. ASHA Suplement 21, 29-32. Rockville, MD.

Barnum, M. (1984). In support of bilingual/bicultural education for deaf children. American Annals of the Deaf, 129 (5), 404-408.

Batterbury, S. (2012). Language Justice for Sign Language Peoples: The UN Convention on the Rights of Persons with Disabilities. Language Policy, 11 (3), 253-272.

Bialystok, E. (2001). Bilingualism in Development: Language, Literacy and Cognition. Cambridge: Cambridge University Press.

Bradarić-Jončić, S. \& Kolarić, B. (2012). Dvojezično obrazovanje gluhe djece [Bilingual education of deaf children]. Hrvatska revija za rehabilitacijska istraživanja, 48 (1), 104-116.

Cummins, J. (2000). Interdependence of First- and Second-language Proficiency in Bilingual Children. In: E. Bialystok (Ed.), Language Processing in Bilingual Children (70-89). Cambridge: Cambridge University Press.

Francis, N. (2005). Bilingual children's writing: Self-correction and revision of written narratives in Spanish and Nahuatl. Lingvistics and Education, 16 (1), 74-92.

Gregory, S. (2004). Issues in sign bilingual education. In: S. Bradarić-Jončić, \& V. Ivasović (Eds.), Sign Language, Deaf Culture and Bilingual Education (111-121). Zagreb: Faculty of Education and Rehabilitation Sciences.

Grosjean, F. (2001). The right of the deaf child to grow up bilingual. Sign Language Studies, 1 (2), 110-114.

Hoffmeister, R. J. (2000). A piece of the puzzle: ASL and reading comprehension in deaf children. In: C. Chamberlain, J. P. Morford, R. I. Mayberry (Eds.), Language Acquisition by Eye (143-164). Mahwah, NJ: Lawrence Erlbaum.

Isaković, Lj. i Kovačević, T. (2015). Komunikacija gluvih i nagluvih-mogućnosti i ograničenja u obrazovanju (Communication of the deaf and hard of hearing-the possibilities and limitations in education). Teme, 39 (4), 1495-1514.

Johnson, R. E., Liddell, S. K., Erting, C. J. (1989). Unlocking the curriculum: The principles for achieving access in deaf education. Washington: Gallaudet University Press.

Komesaroff, L. (2001). Adopting Bilingual Education: An Australian School Community's Journey. Journal of Deaf Studies and Deaf Education, 6 (4), 299-314.

Kovačević, T. (2012). Karakteristike znakovnog i govornog jezičkog izraza kod dece predškolskog uzrasta sa kohlearnim implantom i slušnim aparatima [Characteristics of sign language and verbal expression in preschool children with cohlear implants and hearing aids]. Beogradska defektološka škola, 18 (3), 54, 403-416. 
Kovačević, T. (2013). Funkcija znakovnog jezičkog izraza u razvoju jezika kod gluve i nagluve dece. [Function of sign language expression in the development of language in the deaf and hard of hearing children] (odbranjena doktorska disertacija). Fakultet za specijalnu edukaciju i rehabilitaciju, Beograd.

Kovačević, T., Isaković, Lj., Dimić, N.(2016). Bilingualism with deaf and hard of hearing preschool children. In: S. Nikolić, R. Nikić, V. Ilanković (Eds.), Early Intervention in Special Education and Rehabilitation (347-360). Belgrade: University of Belgrade, Faculty of Special Education and Rehabilitation.

Kovačević, T., Isaković, Lj., Arsić, R. (2017). Pružanje podrške porodici gluve i nagluve dece predškolskog uzrasta [Giving support to family of deaf and hard of hearing pre-school children). U: S. Nikolić (ur.), Zbornik radova naučnog skupa: Prevencija razvojnih smetnji i problema u ponašanju (53-62). Beograd,Srbija: Univerzitet u Beogradu, Fakultet za specijalnu edukaciju i rehabilitaciju.

Knight, P. \& Swanwick, R. (2002). Working with deaf pupils. Sign bilingual policy into practice. London: David Fulton Publishers.

Kreimeyer, K. H., Crooke, P., Drye, C., Egbert, V., Klein, B. (2000). Academic and social benefits of co-enrollment model of inclusieve education for deaf and hard of hearing children. Journal of Deaf Studies and Deaf Education, 5 (2), 174-185.

Luckner, J. L. \& Muir, S. (2001). Successful students who are deaf in general education settings. American Annals of the Deaf, 146, 435-445.

Mahshie, S. N. (2007). Dvojezično obrazovanje gluhe djece. [Bilingual education of deaf children]. Washington, D. C. - Zagreb: Laurent Clerc National Deaf Education Center - Savez gluhih i nagluhih grada Zagreba.

Marschark, M., Schick, B., Spencer, E. P. (2006). Understanding Sign Language. In: B. Schick, M. Marschark, P. Spencer (Eds.), Advances in the sign language development of deaf children (pp. 3-19). New York: Oxford University Press.

Marschark, M., \& Spencer, P. E. (Eds.). (2010). The Oxford handbook of deaf studies, language, and education (Vol.2). Oxford University Press.

Mitchell, R. \& Karchmer, M. (2004). Chasing the mythical ten percent: Parental hearing status of deaf and hard of hearing students in the United States. Sign Language Studies, 4 (2), 138-163.

Perniss, P., Pfau, R., Steinbach, M. (2007). Can't you see the difference? Sources of variation in sign language structure. In: P. Perniss, R. Pfau, M.Steinbach (Eds.), Visible variation: Cross-linguistic studies in sign language structure (1-32). Berlin: Mouton de Gruyter.

Plaza-Pust, C. (2017). Sign Bilingualism in education: challenges and perspectives along the research, policy, practice axis. Germany: Ishara Press.

Reyes, I. (2006). Exploring connections between emergent biliteracy and bilingualism. Journal of early childhood literacy, 6 (3), 267-292. 
Schick, B., Williams, K., Kupermintz, H. (2006). Look who's being left behind: Educational Interpreters and access to education for deaf and hard of hearing students. Journal of Deaf Studies and Deaf Education, 11, 3-20.

Soleša-Grijak, Đ. (2010). Lingvistička kompetencija dece oštećenog sluha kao prediktor uspeha $u$ čitanju [Linguistic competence of children with hearing impairment as a predictor of successful reading]. Pedagogija, LXV (1), 138-147.

So, W. C., Coppola, M., Licciardello, V., Goldin-Meadow, S. (2005). The seeds of spatial grammar in the manual modality. Cognitive Science, 29 (6), 1029-1043.

Strong, M. \& Prinz, P. (2000). Is American Sign Language related to English literacy? In: C. Chamberlain, J. P. Morford, R. I. Mayberry (Eds.), Language Acquisition by Eye (131-142). Mahwah, NJ: Lawrence Erlbaum.

Swanwick, R. A. (2016). Deaf children's bimodal bilingualism and education. Language Teaching, 49 (1), 1-34.

Tang, G., Lam, S., C. Yiu, K. (2014). Language development of deaf and hard-of-hearing students in a sign bilingual and co-enrollment environment. In: M. Marschark, G. Tang, H. Knoors (Eds.), Bilingualism and bilingual deaf education (313-341). New York - Oxford: Oxford University Press.

Titone, H. (1994). Bilingual education and the development of metalinguistic abilities: A research project. International Journal of Psycholinguistics, 10 (1), 5-14.

Willbur, R. B. (2000). The use of ASL to support the development of English and literacy. Journal of Deaf Studies and Deaf Education, 5 (1), 81-104.

TAMAРA Р. КОВАЧЕВИЋ

ЉУБИЦА С. ИСАКОВИЋ

УНИВЕРЗИТЕТ У БЕОГРАДУ

ФАКУЛТЕТ ЗА СПЕЦИЈАЛНУ ЕДУКАЦИЈУ И РЕХАБИЛИТАЦИЈУ

РАДОМИР Б. АРСИЋ

УНИВЕРЗИТЕТ У ПРИШТИНИ СА ПРИВРЕМЕНИМ СЕДИШТЕМ

у КОСОВСКОЈ МИТРОВИЦИ

УЧИТЕљСКИ ФАКУЛТЕТ У ПРИЗРЕНУ - ЛЕПОСАВИЋ

РЕЗИМЕ

БИЛИГВАЛНИ ПРИСТУП У ОБРАЗОВАњУ ГЛУВЕ И НАГЛУВЕ ДЕЦЕ

Билингвизам глуве и наглуве деце подразумева познавање и редовну употребу знаковног језика, који користи заједница глувих и говорног језика који користи чујућа већина. На предшколском и школском узрасту, потребно је омогућити деци да наставе да усвајају језик која су почела да усвајају у породици (знаков- 
ни или говорни). Деца ће најбоље усвојити оба језичка модалитета кроз интеракције са другим флуентним говорницима. Резултати многобројних истраживања указују да је најбољи приступ у процесу развоја говора и језика и образовању глуве и наглуве деце - билингвални приступ. Циљ овог приступа је развити комуникацијске вештине код деце, омогућити им виши ниво образовања и укључити их у живот друштвене заједнице. Неопходно је усавршавање постојећег образовног система у правцу развијања таквог модела који ће да одговори на њихове специфичности и ограничења узрокована њиховим примарним оштећењем.

КључнЕ РЕчи: илингвални приступ; образовање; глува и наглува деца.

Овај чланак је објављен и дистрибуира се под лиценцом Creative Commons Ауторство-Некомерцијално Међународна 4.0 (CC BY-NC 4.0 |

https://creativecommons.org/licenses/by-nc/4.0/).

This paper is published and distributed under the terms and conditions of the Creative Commons Attribution-NonCommercial International 4.0 licence (CC BY-NC 4.0 | https://creativecommons.org/licenses/by-nc/4.0/). 